\title{
Subject English as Citizenship Education
}

\author{
Dr. Oliver Belas \& Dr. Neil Hopkins \\ University of Bedfordshire
}

\author{
Corresponding author: Oliver Belas, Oliver.Belas@beds.ac.uk
}




\section{Abstract}

The following article is equal parts educational history and political philosophy. We aim to remind readers that English (SE) and indeed state education emerge from the contradictory impulses of classical liberalism, and that, more than simply resembling citizenship education, SE emerges in the first instance as a form of highly normativizing citizenship education. We further argue that, following England's recent educational reforms initiated by former Education Secretary Michael Gove, SE continues to be framed in moral terms consistent with citizenship education - again, of a highly normativizing sort. England's current educational policy generally, and specifically the framing of SE, employs the language of liberal possibility, while ultimately espousing an invidious exclusionary and assimilationist politics. The framing of SE, moreover, is one that misrepresents the supposedly 'rich and varied literary heritage' it is supposed to exemplify and promote. The current political landscape in which the study of literature takes place is one where a crisis of liberalism is manifest (in terms of populism, radicalisation or apathy). However, we do not believe the answer is to retreat into a sealed, hermetic canon that excludes the reality that England and English Literature are fundamentally multicultural and polyethnic. SE will be the poorer for not fully acknowledging and embodying this, for not enabling students to imaginatively and critically engage with characters and experiences that reflect both the present and long-standing diversity of English society, as well as its present and long-standing inequalities.

Article word count: 8190 


\section{$\underline{\text { Subject English as Citizenship Education }}^{1}$}

The history of English literature is less the 'internal' history of the literary canon - the procession of one 'great' author followed by another - than it is the history of an academic subject. To tackle that history is to undertake a project of historicizing that must remain aware of its own historiographic - which is to say ideologically seamed; socially, culturally, politically inscribed - processes. 'English Literature' is not a natural or self-evident kind; nor is it ideologically neutral or epistemically frameless (consider for a moment the ideological work done by the definite article: the canon, the history of English literature). There is no one 'natural history' of English literature, nor can 'the English Literary Canon' - the very possibility of which is an expression of power, taste, and bias; an index of (now vocal, now tacit) acquiescence to such expression - be considered the natural raw material which constitutes the field.

In part, the problem is one of common expression. There is an in-built ambivalence of talk, without qualification, of the literary canon, English Literature, or even the history of English Literature, for these abstract nouns operate rather like collective nouns - what is History if not the study of various histories, English Literature if not the study of various literary works and traditions? - and it is often unclear whether what we call 'the canon' is to be imagined as diverse and pluriform, or uniform, univocal, monolithic. As we will see, while the general thrust in literature and language studies has been towards the former, just how far this is reflected in recent educational policy is questionable.

The following is equal parts educational history and philosophy. Subject English (SE) and indeed state education spring in nineteenth-century England from the contradictory impulses of classical liberalism; more than simply resembling citizenship education, SE emerges in the first instance as a form of highly normativizing civic education. Indeed, English education generally has at its 'core,' so to speak, a concern with the moulding of 'good' (that is, desirable) citizens, particularly in the face of an expanding electorate. By 1921, the Newbolt Report would begin with the premise that, language being the vehicle of thought, English was central to any adequate national education which must, of necessity, always have a civic mission (10; see also Doecke 2017). There are, then, three modalities of citizenship education at work in what follows: a political project of nation-building and citizenmoulding; the contemporary subject area - which we refer to as Citizenship Education - as defined in the National Curriculum programmes of study for KS3 and 4 (DfE 2013a); and what we call civic education, those aspects of SE or other curriculum areas that raise civic issues, questions, debates. (We thus follow both Halstead and Pike [2006] and Campbell et al [2012] in their expanded, interdisciplinary conceptions of civic education in schools.)

We further argue that, following England's recent educational reforms initiated by former Education Secretary Michael Gove, SE continues to be framed in moral terms consistent with some project of civic education - again, of a highly normativizing sort. The philosopher Charles Mills $(2005,2014,2015)$ has shown politicalphilosophical liberalism to be a tradition that all too often perpetuates both racism and white supremacism (where 'racism' suggests individual intent, 'white supremacy' socially constituted and constituting racist and racializing structures). England's current education policy generally, and specifically the framing of SE, employs the language of liberal possibility, while ultimately espousing an invidious exclusionary and assimilationist politics, that misrepresents the supposedly 'rich and varied literary heritage' (DfE 2013b, 2; 2014b, 3) it is supposed to exemplify and promote.

We recognise that, though much of what we have to say focuses on the centralized governmental control of subject curricula, it is inaccurate to speak of the centralization of formal education, or schooling, tout court. There is, in fact, a tension between the centralization of curricular content and assessment - a crucial feature of the Goveera and post-Gove politicization of knowledge identified by Yandell (2014) - and the partial decentralization, most pronounced since Blair's "mixed economy" approach to school funding took hold in the late 'nineties, of schools. The rise of mass academization, for example, has brought with it a degree of autonomy; academies can, should they wish, opt out of the National Curriculum. However, given that academies are subject to the same high-stakes inspection criteria as other state-funded schools, just how widely this particular freedom is exercised is questionable. Likewise, independent schools, though they are not bound by the National Curriculum, are nevertheless likely to use subject specifications designed to satisfy National Curriculum requirements. We recognise, too, that the National Curriculum is intended to specify a 'core' - or minimal, not maximal - curriculum. To be sure, many of us could point to instances - whether anecdotal or recorded in the academic literature - of schools' and teachers' working beyond the rigid, baseline requirements of minimal curricula. ${ }^{2}$ We don't dispute such cases; Yandell's defence of the classroom as a site of complex cultural production and meaning-making, '[e]ven in unfavourable circumstances' $(2014,152)$, has us convinced. But surely, the current curriculum is vitiated if the best we can say of it is that 
teachers are creative enough to work around, beyond, or despite it (e.g. Davies 2018). Moreover, there is a danger that if schools run scared of the punitive benchmarks to which they are subject, the minimal curriculum is or will become the maximal curriculum. Yes, academies and other schools may opt out of the National Curriculum; but there are also concerns that, instead, schools are opting out of marginalized subject areas in order to secure their results in 'core' areas (e.g. Whittaker 2018).

It is against such a political state of affairs, then, that our political-philosophical excavation is conducted.

\section{(1) Emergence of Subject English}

As Sanders reminds us, the 'teaching of English began' in eighteenth-century Scotland 'with some clear ideological intent': 'to suppress a certain 'Scottishness",' and to promote instead 'an enlightened European' mindset, an aim that, ironically, gave this early version of SE a distinctively Scottish accent (2000, 7-8). SE in England was not established until the nineteenth century at (then new) institutions such as the University of London; its position was not secured in England's ancient universities until the later-nineteenth and early-twentieth centuries (Sanders 2000, 9). Like the Scottish model, however, English SE aimed at social-moral instruction; and, over the eighteenth and nineteenth centuries, 'the notion that classical works of literature provided moral training consistent with the larger didactic role of schooling served to not only define English as a subject but to also promote the centrality of literature in the school curriculum' (Beach and Swiss 2011).

The emergence of SE in England is thus roughly coincident with the rise, punctuated by the 1870 Education Act, of state education. As Ball has argued, the question of state education at that time expressed a crisis in liberalism, one 'activated by a powerful fear of the working class' (Brehony 1985, qtd. in Ball 2017, 72), and education was understood as a means by which class barriers might be buttressed, not demolished. As Lowe (at the Education Office from 1859 until 1864) put it, in an oft-cited passage, state education was 'a question of selfpreservation,' and he concluded that the lower classes must be educated so 'that they may appreciate and defer to a higher cultivation when they meet it' $(1867,9,32)$.

Lowe is indeed classically liberal - in the critical sense one gets, for example, from Appiah (2005) and Bobbio (1988/1990) - in his ambivalence regarding education. ${ }^{3}$ He is caught between countervailing forces of antidemocratic sentiment, progressive individualism, and egalitarian collectivism:

the voice potential in the Government, is placed in the hands of persons in a lower position of life than has hitherto been the case. It is not merely desirable, it is of the utmost importance, it is necessary for the preservation of the institutions of the country, that those people should be able properly and intelligently to discharge the duties devolving on them. [...] [T] hough I should have been very glad to have allowed the system to have gone on quietly, peacefully, unostentatiously spreading itself, as it has hitherto done, [...] the time has arrived when it is our duty to vindicate for the State its real function in this matter. [...] We cannot suffer any large number of our citizens, now that they have obtained the right of influencing the destinies of the country, to remain uneducated. It was a great evil that we did so before [...]. But now it is a question [...] even of the existence of our Constitution[.] (8-9)

To Lowe's (morally and politically confused) conception of a modern education fit for purpose, English literature and language (as well as modern European languages and histories) are of primary importance over and above Classics. England's literature is 'unparalleled in the world'; and yet, of 'our great classical authors,' a young man at university 'knows nothing of them; and the consequence is that our style is impoverished, and the noble old language of our forefathers drops out of use' $(1867,26)$. Anticipating some of the starting assumptions of the Newbolt Report (1921, ch.1), though with greater enthusiasm for England's 'native' literature than Newbolt, here Lowe articulates the cultural heritage conception of English literature, a conception which runs parallel with a 'political tradition' in which text selection aimed at inculcating students (young men) into certain desirable ways of being (Beach and Swiss 2011; Marshall 200). It is perhaps the predominant characterisation in SE's early educational profile. Joseph Angus, for example, 'Examiner in English Language, Literature and History to the University of London,' expressed similar feeling, declaring English Literature 'the reflection of the national life, an exhibition of the principles to which we owe our freedom and progress: a voice of experience speaking for all time' (Sanders $2000,8)$.

The educative importance of English literature, then, is that it is understood as a source of personalmorality and national identity. It might even - in quasi-Platonic fashion ${ }^{4}-$ help educate members of the various 
classes as to their proper place in society; certainly, as Arnold understood things, 'the education of each class in society has, or ought to have, its ideal, determined by the wants of that class, and by its destination' $(1864,112)$.

\section{(2) Subject English, Diversity, 'Britishness'}

Towards the end of his introductory chapter, Sanders celebrates the broadening, pluralizing, and destabilizing of the English literary canon:

The long-established centrality of certain texts and selected authors [...] has had to give way to the idea of decentralization, much as long centralized nations, including the United Kingdom, have been obliged to consider the implications of devolution and federal association. (2000, 12).

Sanders points to feminist scholarship's centring of literatures by women and revision of received literary history, and to world literature written in English. He is aware of the fruitfully problematic nature of the identification of English literature per se: how are we to position immigrant and emigrant writers in relation to the Englishness of English Literature, for example (2000, 13-14)? Such questions are important precisely because they decentre staid, naturalized conceptions of English literature; and they are perhaps indicative of SE's identity crisis: does 'English Literature' name or refer to (1) the literature(s) of England - let us call this English National Literature (ENL) (a label, however, that does not speak to the issue of in- or ex-clusion of immigrant and emigrant writers, or even to the general issue of which literature(s) to include) - or (2) literature(s) written in English?

Accepting that Sanders has in mind SE in the university, we should not accept unquestioningly this easy narrative of progress, for his optimism is hardly matched by the state of play in England's secondary education. Something a little like definition (2) is, to an extent, still written into SE up to and including KS3 (DfE 2013b \& 2014b). But at KS4, where we find ourselves working with a de facto narrowed conception of the cultural heritage model (see below), the curriculum tends to definition (1).

If at the turn of the twenty-first century, Sanders can claim that ' $\mathrm{n}]$ o twentieth-century commentator could share the imperial presumption of Joseph Angus's sentiment that "no nation can receive and welcome [English Literature] without reproducing in its life the image of our own"” (2000, 13), it must surely be disappointing to find England's Secretary of State for Education boasting in 2015 that

one thing that a child's understanding of Britishness would be incomplete without [is] an appreciation of the vast cultural contribution that our nation has made to the wider world.

Because [...] this small island country has, throughout its history, punched well above its weight as the cultural capital of the world. (Morgan 2015)

Leave aside, for now, the equation of cultural capital with Britishness, and thus of class and national identity; the crass celebration of British colonialism and cultural imperialism. Leave aside, too, the triumphalist language, the pugilistic clichés, the fact that no agency is necessary for the imagined subject-citizen here (one need only appreciate Britain's cultural contribution in order to understand Britishness). Consider just how unwittingly right Nicky Morgan is: while Sanders recognizes the politically motivated and moralizing use of ENL as a nation-building, citizenshaping tool, he says nothing of its use as a 'civilizing' tool imposed upon Britain's colonized peoples. Yet this is how English Literature began to take shape before it was established in the academy at 'home.'

'Nowhere,' argues Vásquez (2013), 'is the connection between language and racism more potent than in the schooling process where income, class, ethnicity, and gender are interlinked with language into a synergistic process of inequality.' This is true of British educational policies in India from the nineteenth century on. Though in the eighteenth century the British followed a policy of accommodation and reconciliation - studying Indian literature and customs, supporting Persian and Sanskrit scholarship - by 1835 English had 'replaced Persian as the language of government records, a change that marked English as the language of political dominance and mobility,' and it was decreed that English education - and here, perhaps, is a crucial link between linguicism and literature as colonial tools - was to receive the greatest funding (Bharadwaj 2011; see also Viswanathan 1989). While, as Gibbons $(2016 ; 2017)$ has argued, English teachers in the middle of the twentieth century commonly thought of their subject in the emancipator terms of Dixon's (1975) personal growth model, we find that in one of its earliest forms SE, alongside serves very different ends, is in fact a mechanism of domination.

With this in mind, it must be remembered that wherever we find the self-conscious rejection of ENL in favour of local, regional, cultural, native, indigenous literatures in English, or where we find the double- 
consciousness of Walcott (1998), who simultaneously identifies with and feels alienated from both English literary tradition and Caribbean cultural mores - wherever we encounter such articulations, the move is made very often in recognition of something rather close to Angus's statement about the mirroring of national cultural life. ENL is eschewed precisely because it is a source and form of colonial epistemology. It is in the recognition of the socialpolitical reality of ENL as an identity-building-and-reflecting force, and the active repudiation of this, that many non-English literatures written in English are grounded. Issues of language rights, linguicism, the linguistic tyranny of patriarchal/colonial cultures are central to projects of decolonization, just as they are to the search for regional and national literatures. This is true, for example, of the search in the early decades of the twentieth century for a 'truly' American literature. It is true of native and diasporic African and Indian literatures in English. It is true of Indigenous American and Canadian literatures and scholarship. ${ }^{5}$

And it is true also of particular cases, such as Selvon's The Lonely Londoners (1956) - the only text by a black author on a prominent exam board's novel cluster entitled Colonisation and its Aftermath (Edexcel 2015). Mills (2015) often turn to (black- and white-authored) literature as a source of insight into structural white supremacism. He argues that society's structural inequalities are constitutive of social worlds; the social may be immaterial (nonphysical) but it is real: we live (in) the social. Mills is therefore able (without resorting to biological essentialism) to treat literature as a source of original insight, expressive of alternative epistemologies. Our point, then, is not that the cluster's other texts - Heart of Darkness (1899), A Passage to India (1924), Huckleberry Finn (1884) - can have nothing to teach us about colonialism, racism, cultural chauvinism. Far from it. Indeed, in his teaching, Mills has turned to Huckleberry Finn, which he couples with a reading of Kant, precisely for Twain's ability to render 'a whole social order [...], a world in which the moral community of full personhood terminates at the boundaries of white skin' $(2015,15)$. But, while one assumes that the intention of the Colonisation and its Aftermath cluster is non- or even anti-racist - designed as an invitation to explore, through literature, the moral ills of racialist and economic imperialism - nevertheless, in this example, the syllabus privileges white, western(ized) perspectives, in the form of canonical literature. ${ }^{6} \mathrm{It}$ is no small irony that here literature appears to have been put, perhaps unwittingly, to its traditional - read, original - ideological task.

\section{(3) Englishness, literature and notions of citizenship}

English literature and its gradual introduction into university and school syllabuses from the early nineteenth century onwards encapsulates, to a significant degree, notions of national and personal identity and, by implications, citizenship (in a broad, non-curricular sense). Literature helps us to navigate our place within the world and identify our place and role within it. Therefore, how English literature is framed in terms of authors, texts and themes is a vital clue into how the powers-that-be regard education, national identity and how literature reinforces or challenges such an identity. Whether it is the influence of Leavis, Scrutiny and 'The Great Tradition' in the 1950s, Gove's recent return to a narrow, traditional canon of established 'classics' for English literature in the National Curriculum, or critics who have argued across the decades for a more expansive, inclusive idea of what constitutes important works of literature in English, the debate is, in significant ways, as much about politics as literary studies.

English is a colonial language. As Mills states in The Racial Contract.

in the colonial enterprise, children in the Caribbean, Africa and Asia were taught out of British, French or Dutch schoolbooks to see themselves as aspirant [...] colored [sic] Europeans, saved from the barbarities of their own cultures by colonial intervention [....] Ngũgĩ wa Thiong'o describes, from his native Kenya, the 'cultural bomb' of British imperialism, which prohibited learning in the oral tradition of Gikuyu and trained him and his school-fellows to see themselves in the alien eyes of H. Rider Haggard and John Buchan $(2014,89)$.

In this stark sense, English literature was used (is used?) to induct colonial peoples into the privileged, metropolitan culture with the sting that, in Mills's words, they would never be able to fully acquire such a culture - there was an acknowledgement, perhaps on both sides, that the acquisition was only ever 'skin deep'. In this light, English and the 'great' literature associated with it could be seen as a tool of subjugation, of conquering 'inferior' peoples through the language and works of a 'higher reason'. This is inevitably a very crude portrayal, and the relationship between the English language, literary studies and the identities of people from the (notionally) English-speaking parts of the Caribbean, Africa and Asia is a complex one. Walcott, the Nobel laureate, has spoken of how studying English literature and history at school in St. Lucia enhanced rather than crippled his Caribbean background and 
heritage - Walcott saw study of English literary 'classics' as a form of empowerment, works in which to compare and critique his homeland. Indeed, Walcott's Omeros has itself become one of those contemporary 'classics', based on Homer's Odyssey and seen by many critics as 'timeless' and yet of its own time and place.

The examples of Walcott and Ngũgĩ has implications for citizenship as well as English Literature. These writers, alongside Solyinka, Rushdie, Jones, Roy and countless others, have challenged and problematised the notion of English as a colonial language in a postcolonial world: in which ways is literary work from Nigerian, Indian, Jamaican and Sri Lankan writers a manifestation of colonial legacy (with the subjugation this implies) and in which ways is it a symbol of English as an expansive and inclusive language, a global lingua franca (Crystal 2012)? If we turn our attentions closer to home, similar questions can be asked of notions of identity and citizenship in contemporary England. If Walcott sees himself as having a dual heritage in terms of his literary training and development, can the same be said and acknowledged with regards to people's views on citizenship in a diverse and multicultural island such as Great Britain? The reality of England as a multicultural entity is not a recent one - it has, all too often, simply gone unacknowledged or been moved to the periphery when discussing national identity (e.g. Doug 2011). However, in the postcolonial period when England has seen successive periods of immigration from what has been termed the 'New Commonwealth' (those countries that achieved independence from the United Kingdom from 1947 onwards), this discussion is necessary and a potentially creative one. Kymlicka writes that a 'state is multicultural if its members either belong to different nations (a multination state), or have emigrated from different nations (a polyethnic state), and if this fact is an important aspect of personal identity and political life' $(1996,18)$. England is thus part of a wider political entity (United Kingdom) that encompasses citizens from different countries (England, Scotland, Wales and Northern Ireland) as well as being 'polyethnic' (to use Kymlicka's term) with regards to people's cultural and national identities. This issue of polyethnicity (although not necessarily using this specific term) has generated considerable (often heated) debate within English political discourse. (We only need to be reminded of Tebbit's infamous 'cricket test' in the 1980s when people of Pakistani, Indian and Bangladeshi heritage were criticised for supporting national cricket teams from these countries when they toured England - the idea being that if you live in England, love cricket and hold a British passport, you should be supporting the English cricket team.) So the question remains: Can you be a citizen of Britain living in England and consider yourself English whilst identifying and celebrating the heritage you bring from the Caribbean, Africa, Asia or elsewhere? One possible answer to this question is offered by Appiah in his description of cosmopolitanism.

According to Appiah, '[o]ne distinctively cosmopolitan commitment is to pluralism. Cosmopolitans think that there are many values worth living and that you cannot live by all of them. So we hope and expect that different people and different societies will embody different values' (Appiah 2007, 144). On the surface at least, the introduction of the 'Fundamental British Values' (FBV) - of 'democracy, the rule of law, individual liberty, and mutual respect and tolerance of those with different faiths and beliefs' (DfE 2014c, 5) - into the English education system looks encouraging. Schools are encouraged to integrate FBV as part of pupils' spiritual, moral, social and cultural (SMSC) development (as stipulated in the Education Act [2002]). FBV could be seen as relatively benign - a statement of values that most 'reasonable' people would conform and adhere to as a means of working and living together within a multicultural society. However, the labelling of these values as 'British' has caused considerable debate (see, for instance, Elton-Chalcraft et al. 2017). There is little that is inherently 'British' regarding the values themselves and it is often taken as read what the concepts themselves actually mean. Fundamental questions occur over whether the curriculum (CE or any other) is a place to induct pupils into a sense of what it means to be British and the relative lack of consultation prior to formulating these particular values as being 'Fundamentally British'. Allied to this is the PREVENT duty which schools and colleges need to comply with in England to prevent political and religious radicalisation as part of the government's existing counter-terrorism strategy (HM Government 2015).

So there are current concerns within English education on how far identity can be explored, either in the context of Citizenship Education or a broader civic education, as part of students' moral, political and spiritual knowledge and development. How accommodating is the English body politic to ideas based on multiculturalism, dual identities and polyethnic states? In what sense is SE, as framed by the National Curriculum, reinforcing certain notions of 'Englishness' and 'Britishness' and marginalizing other identities precisely by positioning them as other? These are questions that Doug (2011) has taken up in some detail, with respect to an older iteration of the GCSE poetry syllabus, and one particular exam board's approach. Though both GCSE and A Level English have undergone significant change since Doug's article, his concerns continue to resonate: 
investment in research for the [exam board's] next edition [of its poetry anthology] is vital if the quality and diversity of poetry - and its ability to engage with pupils and their cultural identity are going to be strengthened.

Perhaps just as importantly, we should be cautious that poetry teaching does not become a mechanistic exercise designed primarily to create nationhood or a national identity. When government agenda starts sweeping into the assessment objectives [...] - where teachers teach a handful of poets by identifying technical aspects - then we have to wonder about what we are doing through poetry. Are we just trying to teach pupils to identify different components of a poem or are we, through the appreciation of aestheticism and the workings of our living language, genuinely interested in developing pupils' understanding of humanity? $(2011,454)$

A further worry is that there is a perceived narrowing of identities associated with the actual narrowing of the minimal curriculum, and that students who do not 'conform' or 'align' with these identities are seen as 'outsiders' having to justify their continued existence and allegiance (see, for instance, the interview between Baroness Warsi and Marr on radicalisation and perceptions of the PREVENT strategy within some British Asian communities [BBC 2017]). As an antidote to the thought that people with dual or multiple heritage or identity are a threat to the 'host' country, Kymlicka offers this salutary comment: 'The experience to date suggests that first- and second-generation immigrants who remain proud of their heritage are also among the most patriotic citizens of their new countries' (Kymlicka 1996, 178). It is the dynamic between identity, history, culture and society where literature has such a fundamental role to play in relationship to contemporary citizenship. The inclusivity or exclusivity of either of these will have long-term ramifications for what it means to be English and what it also means to be a reader or writer of literature in English. As we prepare for the political and social landscape post-Brexit, we have a warning from Mounk $(2018,8)$ :

Liberal democracies are full of checks and balances that are meant to stop any one party from amassing too much power and to reconcile the interests of different groups. But in the imagination of the populists, the will of the people does not need to be mediated, and any compromise with minorities is a form of corruption.

Literature is one area where we can begin to associate and empathise with people from other backgrounds and beliefs. When we narrow the parameters of what we read (or encourage students to read) we are, in effect, narrowing our social and imaginative world. The potential costs of this are hard to quantify.

\section{(4) SE and what it means to be an educated person}

As well as an imaginative locus in which we might associate with and develop moral feeling for others, SE is also conceived as, to borrow from Taylor (1989), a potential source of self. Indeed, as the Department for Education puts it: 'Through reading in particular, pupils have a chance to develop culturally, emotionally, intellectually, socially and spiritually. Literature, especially, plays a key role in such development' (DfE 2013b, 2, \& 2014b, 3). If literature is indeed understood as a source of self, the framing here is sufficiently broad that 'self' might be imagined at the social-political level of abstract ideal citizens and ways of life (Angus's reflection of national cultural life), or at the level of personal identity- or subject-formation. As we have suggested, Lowe's arguments in favour of English literature study concern the moral duty and political expediency of educating an expanded, increasingly proletarian polity - so 'that they may appreciate and defer to a higher cultivation when they meet it' - and the recognition and preservation of a rich, English literary vernacular. If literature is a source of the self, then in Lowe's conception it is a highly normativising source.

There is, however, an alternative tradition of literary-moral thinking, of course, which stresses the transformative potential of literature, the opening of challenges and questions, rather than moral-civic prescriptivism. This Romantic and post-Romantic view is expressed (varyingly) by the likes of Blake (2008), Wordsworth (1992; McEathron 2001), Shelley and others (J. Wordsworth 2001); is continued philosophically in the 'continental' tradition (Derrida 1992; Deleuze 1997; the later Heidegger 1975; Merleau-Ponty 1973; see also Rorty 1989); and is articulated in educational literature in the personal growth model of SE (as noted above) (Dixon 1975). The post-Romantic attitude, dominant among English teachers from the middle of the twentieth century until the 1980s or '90s, appears in recent years to have diminished (Gibbons 2016, 2017). Gove, the architect of the recent educational reforms and current curriculum in England, thinks of English - the literary heritage, its moral affect - in 
the normative and naturalist terms we wish to challenge, and so we end with an analysis of a speech he gave in 2013, while still Education Secretary, entitled 'What does it Mean to be an Educated Person?' We offer this as illustration of the persistence in current government thinking and curricular framing of the contradictory impulses of liberalism we identified earlier.

Gove's speech opens with a series of tendentious hypotheticals. For example: 'You come home to find your 17year-old daughter engrossed in a book. Which would delight you more - if it were Twilight or Middlemarch?' In each case, the 'good' choice - that is, the choice that 'sensible,' 'rational,' 'aspirational' parents (like Us) would make - is clear, a matter, it seems, of 'common sense.' After further preliminaries, Gove gets down to curricular matters. English first. He stakes the argument out on familiar ground and in familiar terms: this is a fight over high and low standards, duked out between those who, having high aspirations for young persons, believe in a knowledge-rich curriculum, and those who do not. He bemoans the low standards that have become the norm, and offers examples of four schools (mostly primary) that have dared implement more than usually challenging English curricula.

In a list that cites around 30 individual texts or authors, four - Austen, Naidoo, Laird, and Doherty - are women. This discounts Twilight author Meyer, who is mocked again at the close of this section: 'There is a Great Tradition of English Literature - a canon of transcendent works - and [Meyer] is not part of it.' Of the 26 men listed, one - Gladwell - is not white. Of the remaining 25 male writers, Dickens and Pullman are each named twice, while Shakespeare is referenced, either by name or work, eight times. We are being tendentious here, of course one might carve a list up according to (identitarian) categories other than race and gender (see Pike 2015, ch.10) but Gove's selection and selectivity shouldn't go unremarked, particularly as, in the context of a speech pressing the case for curricula reform, this list is presumably to be taken as an expression of 'our rich and varied literary heritage' (DfE 2013b, 2, \& 2014b, 3). One wants to ask: 'rich and varied' according to what (and whose) criteria? Who is the 'we' imagined in 'our'? Such questions echo the concerns not only of Doug (2011) but also of Pike (2015, 155-61), whose 'ethical English' model places SE very much in the context of civic education, and who, in dialogue with Doug, is sensitive to the inherent difficulties any exam board faces when trying to represent fluid multiculturalism in the ossifying, categorising form of the anthology.

Earlier in the SE section of the speech, Gove extols, in support of KS 2 grammar tests, the socially enabling virtues of 'correct' English. His comments are a refutation of a Guardian article in which Michael Rosen (2013) criticises the proposed tests. In Gove's inaccurate summary, Rosen's complaint is that there should be no grammar tests because there is 'no such thing as correct grammar' (Gove 2013). In response, Gove, drawing no doubt on his experience as a journalist, reminds his audience that the Guardian

has a style guide, a team of trained sub-editors and a revise sub-editor as well as a night editor and a backbench of assistant night editors to ensure that what appears under his - and everyone else's - byline is correct English.

Rosen's claim is, in fact, not that there is no such thing as standard grammar, but that, at base, there is no absolute consensus among expert grammarians and linguisticians over grammar; he also points to the inevitability of language change (from above and below). Such uncontroversial claims can be learned from standard reference texts on English language and linguistics (e.g. Crystal 2003; Finch 2000). Few students of language would suggest there are no linguistic-grammatical norms. But these norms are societally set and thus socio-historically contingent; they do not swing free of such political, economic, and moral issues as class, gender, sexism, racism, colonialism (e.g. Millroy \& Millroy 1991; Phillipson 1992).

We mention this not to adjudicate between Rosen and Gove, but so that we might begin teasing out parallels between Gove's views on English language and literature: his belief in a single correct standard of language use bolsters and is bolstered by his belief in a single Great Tradition of English Literature. Moving seamlessly from concern over low levels of functional literacy - the opinions of children's authors Wilson and Hill are cited as evidence (Gove 2013; see Mesure 2013 and Paton 2008) - to literature curricula, as if to imply that the quality, were it measurable, of the latter is necessarily tied to outcomes in the former, Gove performs a remarkable sleight of hand. In the above block quote from Gove (2013), Standard English - properly thought of as a dialect or vernacular once but no longer tied to a region (bounded by Oxford, Cambridge, and London) - has become 'correct English,' as if it were an absolute standard, or, perhaps, like Gove's imagined canon, 'transcendent.' Additionally, particular syllabi or curricula are presented as functions or expressions of the Great Literary Tradition. Speaking of language and literature as if stable, 'transcendent,' - and ignoring the fact that the movement of literature studies and 
sociolinguistics has been towards plurality, diversity, difference, and change - Gove implies an equivalence of moral duties: the moral duty to teach the 'correct' English language is also the moral duty to teach 'the Great Literary Heritage' (as well as the moral duty not to teach Twilight).

Lowe, Gove, and, in a subtler and more confused way, Morgan all work from a deficit model that confers culture upon the haves and strips it from the have-nots. The rationale for SE is couched in the language of liberal possibility, but underpinned by an exclusionary and assimilationist philosophy. Gove's overt claim is that Michael Rosens don't want poor kids to have the same educational rights as rich kids; his implicit claim, however, is that poor kids needs to speak and act like rich kids, because that is the 'correct' (read convenient or expedient) way to be. Shades here of Bernstein's (2000) well-known dualism of restricted and elaborated codes, the basic claim of which is that the linguistic competence of lower-class young people is deficient, restricted, and thus disadvantages them relative to their more linguistically skilled middle-class peers. When Gove (2013), responding to Rosen, says that only 'a funny form of progressivism would claim 'that the knowledge which elites have used to communicate with confidence and authority over the years - and which they pay to ensure their children can master - should be denied to the majority of children,' he is going along with the deficit narrative, the solution to which is assimilation to a 'standard' presented as value-neutral but which is in fact highly class- and race-bound.

As Michael Rosen's father Harold (1974) pointed out, drawing on Labov's study of black vernacular English, Bernstein's dualism appeared to be based on little more than a stereotypical deficit view of working- or lower-class linguistic competence. Labov (1972) found in his study of black vernacular English that, in terms of communicative efficacy and complexity, there is little evidence of the superiority of Standard English. Quite the opposite; and, nearly a half-century after first publication, his empirical work remains pertinent to the English educational scene.

Labov (1972) finds that 'in many ways working-class speakers are more effective narrators, reasoners, and debaters than many middle-class speakers who temporalize, qualify, and lose their argument in a mass of irrelevant detail' (213-14), He also suggests that the 'explicitness and precision which we hope to gain from copying middleclass forms are often the product of the test situation, and limited to it' (221). The explicitness and precision associated with and aimed at in middle-class styles of speech, moreover, are often found only in writing; middleclass-styled speech generally 'departs maximally from this target' (222). Comparing examples of lower-class black vernacular and middle-class speech, Labov suggests that far from being 'flexible, detailed and subtle,' Bernstein's elaborated code is, just as often, 'also turgid, redundant, bombastic and empty,' and he asks whether this code is 'not simply an elaborated style, rather than a superior code or system?' (213). Labov does not deny the importance of functional literacy, but he challenges the general acceptance of any deficit model of vernacular Englishes and crucially - their speakers, which would transfer 'real defects of our educational system to imaginary defects of the child' (202). In the cases we have considered above, the games of diagnosis and blame are a little different. Defects are located in children, but these are posited as evidence of a substandard education system, which the reforms will fix.

If the literary canon is the, or $a$, source both of elaborated speech and a (shared or personal) self, then what Gove is proposing is a mode of national identity which, like Morgan's words on Britishness and culture, is chauvinistic in import, regardless of intent. The overt message may be 'liberty, through education, for all.' But the means is through assimilation to a standardized linguistic mode of being. (The very mode, let it be noted, that leads both hand-wringing when it is thought absent, and to accusations of precisely the empty bombast Labov identifies when it is in the mouths of politicians and academics. ${ }^{7}$ ' The classically liberal contradiction, once more, between individualism and universalism, resolved by presenting a culturally specific model as a culturally neutral, universal ideal. Labov's arguments still resonate: little wonder that we should everywhere find deficit, if deficit is what we call difference imagined as deviations from a norm or standard, derived from an idealised model itself drawn from a privileged, powerful minority.

\section{Conclusion}

Unsurprisingly, the language of the DfE's Programmes of Study for English at KS3 and 4 is a little more measured and less crudely politicized than the rhetoric of Gove's speeches, which are not, of course, policy but defences of it. It is also true that the current curriculum has no specified texts, and, other than Shakespeare, no specified authors. But consider some of the guidance, first for reading at KS3 (2013b, 4), then KS4 (2014b, 5):

Pupils should be taught to: 
- develop an appreciation and love of reading, and read increasingly challenging material independently through:

- reading a wide range of fiction and non-fiction, including in particular whole books, short stories, poems and plays with a wide coverage of genres, historical periods, forms and authors. The range will include high-quality works from:

- English literature, both pre-1914 and contemporary, including prose, poetry and drama

- Shakespeare (two plays)

- seminal world literature

Pupils should be taught to:

- read and appreciate the depth and power of the English literary heritage through:

- reading a wide range of high-quality, challenging, classic literature and extended literary non-fiction, such as essays, reviews and journalism. This writing should include whole texts. The range will include:

- at least one play by Shakespeare

- works from the 19th, 20th and 21st centuries

- poetry since 1789 , including representative Romantic poetry

- re-reading literature and other writing as a basis for making comparisons

- choosing and reading books independently for challenge, interest and enjoyment.

Our concern is not with the specificity of the curriculum. It is, rather, with the way the apparent latitude of the curriculum can lead to a significant narrowing of cultural scope. How are we to read the 'world' of 'seminal world literature'? As national, cultural, ethnic, racial other to England's Great Tradition (once again, see Doug 2011)? 'World literature' is a highly problematic category in a postcolonial but not yet decolonized context, and there is, in any case, little evidence of it in the examples Gove (2013) cites (possibly, one might count Naidoo and SaintExupéry). No matter; these problems are dealt with by KS4 because 'seminal world literature' simply disappears. (At A Level, it should be mentioned, literature in translation is explicitly proscribed, and we have mentioned the example of Selvon.) One wants to ask, then, just how 'rich and varied' a 'literary heritage' students are likely to experience at school-level SE. Certainly, at KS4, for various reasons, once Shakespeare, the Romantics, at least one nineteenth-century prose text, and a collection of poetry spanning the Renaissance to the present have been studied in sufficient detail for students to confidently tackle a series of closed-book examinations, there may be limited scope for further enrichment or diversification (see DfE 2014b): to return to an earlier point, one concern is when the minimal becomes the maximal curriculum.

Few people - us included - would suggest that learning to read and write Standard English is unimportant; and we do not wish to be charged with wanting to deny poor kids access to certain modes of thinking, speaking, writing, and being. Labov (1972) is himself aware of the advantages that Standard English has in certain contexts or practices (such as meta-linguistic analysis); we, too, take it for granted that control and flexibility over, the inhabiting of, language - written as well as spoken - is empowering. And though we cannot turn to it in any detail here, we believe that Young's carefully theorized and contextualized work on 'powerful knowledge' offers a more fruitful discussion than Gove's Hirschean turn to 'core knowledge' (e.g. Gove 2009, 2014; Hirsch 1987). (Indeed, Young offers possible conciliation between Bernstein, on the one hand, and the likes of Harold Rosen and Labov on the other.) The criticisms we make are directed at a 'mission creep' of sorts that has occurred over the last twenty-or-so years. As Wyse et al $(2018,78)$ point out, the contextualized approach to Standard English found in the Cox Report (DES 1989) - and, one might add, to an extent also in the Bullock and Kingman Reports $(1975 ; 1988)$ - has been displaced by the 'untenable' idea that Standard English is a virtually invariant, stable, world-wide lingua franca. And it is troubling indeed to consider that, following Kingman and Cox, the government-commissioned teacher-support materials were withdrawn by government, possibly because the materials were thought downplay the importance of Standard English and to have insufficiently decontextualized their accounts of language (see Carter 1997, ch.3). As Wyse et al $(1989,126)$ are aware, this creep over the last two decades suggests a pernicious identity politics at work in 
educational policy, one, we would add, that fails to recognise the mutability of multicultural society (see Doug 2011; Pike 2015).

We contest any model of SE and English education that fails to recognize its own history and historicity; fails to recognize that SE, and the liberalism from which it emerges, is enmeshed with histories of colonialism and class; fails to recognize that SE is an expression of the cultural chauvinism of political and philosophical liberalism; and fails to recognize that Standard English is not 'correct' English, but rather a dialect or vernacular, privileged, yes, but a vernacular nonetheless (a fact, as noted, recognized by the Bullock, Kingman, and Cox Reports). Pace Labov and Harold Rosen, we reject any deficit model of SE that presumes most native speakers of English do not 'know' their own language, are, in effect, dispossessed of the validity and richness of their language, because they do not speak the ('correct') language 'properly.' This rejection is not the same as saying that English teachers are not faced with assisting in the enabling and empowering of students (once more, we would turn here not to Gove, or to Hirsch, but to Young). Empowerment as imitation of and conformity to a standard, however, is not empowerment.

Among those writers Gove venerates, one finds slang, dialects, vernaculars celebrated as sources of poetic richness and insight. We find this in Wordsworth (1992), whom Gove (2013) admires above all others, and in Whitman's celebration of slang (1885). Perhaps the greatest irony of the yoking of 'correct' English and the Great Literary Tradition is that we lose sense of English literature as a vernacular or multiplicity of vernaculars, and of the collective history of 'great' literature being one not of conformity but of deviancy, change, and challenge (e.g. Deleuze 1997; Derrida 1992). If, as we are also claiming, SE is itself (potentially or, often, actually) a form of civic education, then the framing and presentation of 'the' canon and books to be studied may well have implications for how students interpret their own identities when they engage with literature. The emergence of English as a 'world language' (or even as a set of transnational Standard Englishes) has both enriched and problematized the notion of literature as a form of English national identity (in the manner of Lowe). The current political landscape in which the study of literature takes place is one where a crisis of liberalism is manifest (in terms of populism, radicalisation or apathy). However, we do not believe the answer is to retreat into a sealed, hermetic canon that excludes the reality that England and English Literature are fundamentally multicultural and polyethnic. ${ }^{8}$ To both draw from and move beyond the thinking of philosopher John Rawls (2005) - whose own accounting for, or rather erasure of, race, and whose idealizing away from the structural and epistemic realities of race, are highly problematic (see Mills 2005, 2014, 2015) - multiculturalism is not an aberration but an integral aspect of, essential to, contemporary democratic societies; unfortunately, as Mills (2014; 2015), among others, has shown, so too is structural white supremacy. English Literature in schools and colleges is poorer for not fully acknowledging this, for not enabling students to imaginatively and critically engage with characters and experiences that reflect both the present and long-standing diversity of English society, as well as its present and long-standing inequalities. 


\section{References}

Appiah, K. A. (2005) The Ethics of identity (Princeton, Princeton University Press).

--- (2007) Cosmopolitanism: Ethics in a world of strangers (London, Penguin).

Arnold, M. [1864.] A French Eton, or middle-class education and the state, in: P. Smith and G. Summerfield (Eds). Matthew Arnold and the education of the new order (Cambridge, Cambridge University Press, 1969).

Ball, S. J. (2017) The Education Debate, $3^{\text {rd }}$ Ed. (Bristol, Policy Press).

Beach, R., and Swiss, T. (2011) Literary theories and teaching of English language arts, in: D. Lapp \&

D. Fisher (Eds), Handbook of research on teaching the English language arts., $3^{\text {rd }} \mathrm{Ed}$. (London, Routledge).

Bernstein, B. (2000) Pedagogy, symbolic control and identity: Theory, research, critique, Rev. Ed. (Lanham, Rowman \& Littlefield).

Bhabha, H. K. (1994) The Location of culture (London, Routledge).

Bharadwaj, V. (2011) British educational policies in India, in: A.J. Andrea (ed.), World History Encyclopedia (Santa Barbara, ABC-CLIO).

Bobbio, N. [1988/1990.] Liberalism and democracy, trans. M. Ryle and K. Soper (London, Verso, 2005).

Brehony, K. (1985) Popular control or control by experts? Schooling Between 1880 and 1902, in: M. Langan \& B. Schwartz (Eds), Crisis in the British state 1880-1930 (London, Hutchinson).

Campbell, D.E., et al (2012) Making civics count: Citizenship education for a new generation (Cambridge, MA: Harvard University Press).

Carter, R. (1997) Investigating English discourse: Language, literacy and literature (London: Routledge).

Conrad, J. [1899] Heart of darkness, in: P. B. Armstron (Ed.) Norton Critical Edition, $4^{\text {th }}$ Ed. (New York, Norton, 2006).

Coulthard, G. S. (2014) Red skin, white masks: Rejecting the colonial politics of recognition (Minneapolis, University of Minnesota Press).

Coward, R. (2017) Theresa May takes empty rhetoric to a new level, The Guardian, 28 March. Available online at: https://www.theguardian.com/commentisfree/2017/mar/28/theresa-may-rhetoric-brexit-authoritariandelusions (accessed 14 June 2018).

Davies, M. (2018) 'Doing' persuading: Actively constructing knowledge, voice and self, Changing English: Studies in Culture and Education 25(3), 264-274. DOI: 10.1080/1358684X.2018.1482738.

Departmental Committee, Board of Education [1921] The Teaching of English in England (London: His Majesty's Stationery Office, 1926). [Cited in text as the Newbolt Report.]

Department of Education and Science (1975) A language for life (London: Her Majesty's Stationery Office). [Cited in text as the Bullock Report.]

--- (1988) The teacbing of English Language (London: Her Majesty's Stationery Office). [Cited in text as the Kingman Report.]

--- and the Welsh Office (1989) English for ages 5 to 16 (London: Her Majesty's Stationery Office). [Cited in text as the Cox Report.]

DfE (2013a) Citizenship programmes of study: Key stages 3 and 4 national curriculum in England. Available online at: https://assets.publishing.service.gov.uk/government/uploads/system/uploads/attachment data/file/239 060/SECONDARY national curriculum - Citizenship.pdf (accessed 10 October 2018).

--- (2013b) English programmes of study: Key stage 3 national curriculum in England. Available online at: https://assets.publishing.service.gov.uk/government/uploads/system/uploads/attachment data/file/244 215/SECONDARY national curriculum - English2.pdf (accessed 03 June 2018).

--- (2014a) National Curriculum in England: framework for key stages 1-4 (DfE). Available online at: https://www.gov.uk/government/publications/national-curriculum-in-england-framework-for-key-stages1-to-4/the-national-curriculum-in-england-framework-for-key-stages-1-to-4\#introduction (accessed 03 June 2018).

--- (2014b) English programmes of study: Key stage 4 National Curriculum in England (DfE). Available online at: https://assets.publishing.service.gov.uk/government/uploads/system/uploads/attachment data/file/331 877/KS4 English PoS FINAL 170714.pdf (accessed 03 June 2018).

Dixon, J. (1975) Growth through English: Set in the perspectives of the seventies (Oxford, Oxford University Press).

Doecke, B. (2017) What kind of 'knowledge' is English? (Re-reading the Newbolt Report), Changing English: Studies in Culture and Education 24(3), 230-245. DOI: 10.1080/1358684X.2017.1351228.

Doug, R. (2011) The British schools' National Curriculum: English and the politics of teaching poetry from 'different cultures and traditions,' Journal of Curriculum Studies 43(4), 439-456. 
Eaglestone, R. (2009) Doing English: A Guide for literature students, $3^{\text {rd }}$ Ed. (Abingdon, Routledge).

Edexcel (2015) AS and A Level English Literature. [Landing site.] Specifications and other materials available online at: https://qualifications.pearson.com/en/qualifications/edexcel-a-levels/english-literature-

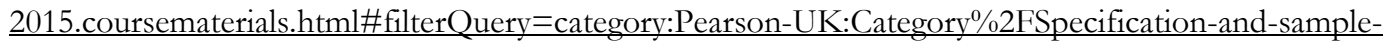
assessments (accessed 18 May 2018).

Forster, E.M. [1924.] A Passage to India (London, Penguin, 2005).

Gibbons, S. (2016) W(h)ither the radicals? English in Education 50(1), 35-43.

--- (2017) English and its teachers: A History of policy, pedagogy and practice (London, Routledge/NATE).

Gov.UK (n.d.) Types of school. Available online at: https://www.gov.uk/types-of-school (accessed 10 October 2018).

Gove, M. (2009) What is education for? Speech to the RSA. Available online at: https://www.thersa.org/globalassets/pdfs/blogs/gove-speech-to-rsa.pdf (accessed 03 October 2018)

--- (2013) What does it Mean to be an Educated Person? Available online at: https://www.gov.uk/government/speeches/what-does-it-mean-to-be-an-educated-person (accessed 03 June 2018).

--- (2014) Michael Gove speaks about the future of educational reform. Available online at: https://www.gov.uk/government/speeches/michael-gove-speaks-about-the-future-of-education-reform (accessed 01 October 2010).

Halstead, J.M., and Pike, M.A. (2006) Citizenship and Moral Education: V alues in Action (Abingdon: Routledge). Hirsch, E.D. (1987) Cultural literacy: What every American needs to know (Boston: Houghton Mifflin Harcourt). Hutchinson, G. (1995) The Harlem Renaissance in black and white (Massachusetts, Belknap Press-Harvard University Press).

King, T. (2003) The Truth about stories: A Native narrative (Toronto, House of Anansi Press).

Labov, W. (1972) Language in the inner city: Studies in the Black English Vernacular (Oxford, Basil Blackwell). Lagasse, P. (Ed.) (2017) Liberalism, in: The Columbia encyclopedia, $7^{\text {th }}$ Ed. (New York, Columbia University Press).

Learmonth, A. (2017) Michael Gove sets out reforms for post-Brexit farm subsidies which could pose threat to those in Scotland, The National. Available online at:

http://www.thenational.scot/news/15427712.Michael Gove sets outs reforms for post Brexit farm s ubsidies which could pose threat to those in Scotland/ (accessed 16 June 2018).

Lowe, R. (1867) Primary and classical education: An Address. Delivered before the Philosophical Institution of Edinburgh on Friday, November 1, 1867 (Edinburgh, Edmonston and Douglas. [Available electronically through the Wellcome Library: https://dlcs.io/pdf/wellcome/pdf-item/b21964798/0 (accessed 18 May 2018).

Maracle, L. (1996) I am woman: Native perspective on sociology and feminism (Vancouver, Press Gang Publishing).

Marshall, J. (2000) Research on response to literature, in: M.L. Kamil et al (Eds.) Handbook of Reading Research Vol. III (Mahwah, NJ, Erlbaum).

McEathron, S. (2001) Wordsworth and Coleridge, Lyrical Ballads, in: D. Wu (Ed.), A Companion to Romanticism (Oxford, Blackwell).

McLeish, K. (Ed.) (1993) Liberalism, in: Bloomsbury Guide to Human Thought (London, Bloomsbury).

Mesure, S. (2013) Jacqueline Wilson: 'Spelling is not something that seems to be taught at schools,' Independent, 5 May. Available online at: https://www.independent.co.uk/news/education/education-news/jacquelinewilson-spelling-is-not-something-that-seems-to-be-taught-at-schools-8604485.html (accessed 14 June 2018).

Mills, C. W. (2005) 'Ideal theory' as ideology, Hypatia 20(3), 165-184.

--- (2014) The Racial contract [e-book] (Ithaca, Cornell University Press).

--- (2015) Blackness visible: Essays on philosophy and race (Ithaca, Cornell University Press).

Milroy, J. \& Milroy, L. (1991) Authority in language: Investigating language prescription and standardization (London, Routledge).

Morgan, N. (2015) The Arts underpin our understanding of Britishness, 16 July. Available online at: https://www.gov.uk/government/speeches/the-arts-underpin-our-understanding-of-britishness (accessed 1 February 2018).

Ngũgĩ wa Thiong'o (1981) Decolonising the mind: The Politics of language in African literature (Nairobi, East African Educational Publishers).

Paton, G. (2008) 'Ignorant' students flood author with essay requests, The Telegraph, 28 November. Available online 
at: https://www.telegraph.co.uk/education/secondaryeducation/3533667/Ignorant-students-floodauthor-with-essay-requests.html (accessed 14 June 2018).

Pike, J. (Ed.) (2007) Liberalism, in: Political philosophy A-Z (Edinburg, Edinburgh University Press).

Pike, M.A. (2015) Ethical English: Teaching and learning in English as spiritual, moral and religious education (London: Bloomsbury)

Phillipson, R. (1992) Linguistic imperialism (Oxford, Oxford University Press).

Plain English Campaign [landing site]. Available online at: http://www.plainenglish.co.uk/ (accessed 14/06/2018).

Rivkin, J. \& Ryan, M. (1998) English without shadows, literature on a world scale, in: Rivkin \& Ryan (Eds), Literary theory: An Anthology, Rev. Ed. (Oxford, Blackwell).

Rorty, R. (1989) Contingency, Irony, and Solidarity (Cambridge: Cambridge University Press).

Rosen, H. [1974] Language and class: A Critical look at the theories of Basil Bernstein, in: Writings on life, language and learning, 1958-2008, J. Richmond (Ed.) (London, UCL IOE Press, 2017).

Rosen, M. (2013) Dear Mr Gove: Michael Rosen's letter from a curious parent, The Guardian, 6 May. Available online at: https://www.theguardian.com/education/2013/may/06/michael-rosen-letter-to-michael-gove (accessed 03 June 2018).

Rushdie, S. [1982]. Imaginary homelands, in: Rushdie, Imaginary homelands: Essays and criticism 1981-991 (London, Granta/Penguin, 1992).

Sanders, A. (2004) The Short Oxford history of English literature, $3^{\text {rd }}$ Ed. (Oxford, Oxford University Press).

Selvon, S. [1956] The Lonely Londoners (London, Penguin, 2006).

Simpson, L. B. (2017) As We have always done: Indigenous freedom through radical resistance (Minneapolis: University of Minnesota Press).

Thompson, M. (2016) From Trump to Brexit rhetoric: how today's politicians have got away with words, The Guardian. 27 August. Available online at: https://www.theguardian.com/books/2016/aug/27/fromtrump-to-brexit-rhetoric-how-todays-politicians-have-got-away-with-words (accessed 14 June 2018).

Twain, M. [1884.] The Adventures of Huckleberry Finn (London, Penguin, 2003).

Vásquez, O. (2013). Language, in: P.L. Mason (Ed.), Encyclopedia of race and racism, $2^{\text {nd }}$ Ed. (Farmington: Gale).

Viswanathan, G. (1989) Masks of conquest: Literary study and British rule in India (New York: Columbia University Press).

Walcott, D. (1998) What the twilight says: Essays (London, Faber and Faber).

White, N. (2018a) GCSE text book 'stereotypes' Caribbean families by claiming that dads are 'largely' absent, Huffpost, 07 October. Available online at: https://www.huffingtonpost.co.uk/entry/aqa-book-authorsunder-fire-for-stereotyping-caribbean-families uk 5bb9626de4b01470d051e48f (accessed 08 October 2018).

--- (2018b) More offensive statements found in GCSE textbook pulled from shelves amid charges of racism, Huffpost, 17 October. Available online at: https://www.huffingtonpost.co.uk/entry/offensive-statementsgcse-textbook uk 5bc4af5ce4b0bd9ed55c8325 (accessed 17 October 2018).

Whittaker, F. (2018) Music is 'at risk of disappearing' from schools, research finds, Schools Week. Available online at: https://schoolsweek.co.uk/music-is-at-risk-of-disappearing-from-schools-research-finds/ (accessed 10 October 2018)

Williams, R. (1976) Keywords: A Vocabulary of culture and society (Glasgow, Fontana).

Wordsworth, W. (1992) Lyrical Ballads, Michael Mason (Ed.) (London, Longman).

Wyse, D., et al (2018) Teaching English, Language and Literacy, 4th Ed. (Abingdon: Routledge).

Yandell, J. (2014) Classrooms as sites of curriculum delivery or meaning-making: whose knowledge counts? Forum $56(1), 147-155$

Young, M., and Muller, J. (2013) On the powers of powerful knowledge, Review of Education 1(3), 229-250. DOI:

$10.1002 /$ rev3.3017 
${ }^{1}$ Note for readers unfamiliar with England's education system: Primary education covers Key Stages (KS) 1-2, secondary 34. KS3 is preparatory for KS4, which culminates in national exams taken when students are 15 or 16 years old. A Levels/KS5 are England's 'traditionally' academic level 3 qualifications (DfE 2014a). Academy schools are quasi-autonomous but, unlike truly independent schools, state funded institutions. For definitions of the various schools models/statuses, see Gov.UK 'Types of School.'

2 Our thanks to one of the anonymous reviewers for making this point.

${ }^{3}$ For further illustration of liberalism's plural and often contradictory history and nature, see encyclopaedic or reference-work entries, e.g. McLeish (1993), Lagasse (2017), Pike (2007).

${ }^{4}$ Lowe, in fact, is explicit in his admiration of Plato $(1867,5-6)$.

5 On the search for an American national literature, and the place of African American cultural production, see Hutchinson (1995). On diasporic literatures, see Rivkin \& Ryan (1998); Bhabha (1994); Rushdie (1982); Ngũgĩ (1981). On Indigenous American and Canadian culture and decolonization, see Coulthard (2014); Justice (2018); King (2003); Maracle (1996); Simpson (2017).

${ }^{6}$ Several months after this piece was researched and drafted, a starker example of such structural-perspectival privileging was reported: KS4 sociology textbook was withdrawn because it contained numerous 'innocent' thought undeniably racist or culturally chauvinistic comments (White 2018a/b).

${ }^{7}$ For examples of deficit-inspired hand-wringing, see Paton (2008), reporting on Hill's concerns; see also Mesure (2013) on Wilson. These are the stories to which Gove (2013) refers as evidence of poor literacy standards. Accusations of politicians' 'empty rhetoric' abound, to the point where wonders whether 'empty rhetoric' might be in danger of being emptied out. For recent examples, see Coward (2017), Learmonth (2017), Thompson (2016). See also the various awards and examples offered by the Plain English Campaign

8 On Britain's long multiracial history, see Fryer (1984). 